\title{
Article
}

\section{Risk Analysis of Road Tunnels: A Computational Fluid Dynamic Model for Assessing the Effects of Natural Ventilation}

\author{
Ciro Caliendo*(D), Gianluca Genovese (D) and Isidoro Russo \\ Department of Civil Engineering, University of Salerno, 84084 Fisciano, Salerno, Italy; ggenovese@unisa.it (G.G.); \\ isrusso@unisa.it (I.R.) \\ * Correspondence: ccaliendo@unisa.it; Tel.: +39-8996-4140
}

Citation: Caliendo, C.; Genovese, G.; Russo, I. Risk Analysis of Road Tunnels: A Computational Fluid Dynamic Model for Assessing the Effects of Natural Ventilation. Appl. Sci. 2021, 11, 32. https://dx.doi.org/10.3390/app11 010032

Received: 1 December 2020

Accepted: 21 December 2020

Published: 23 December 2020

Publisher's Note: MDPI stays neutral with regard to jurisdictional claims in published maps and institutional affiliations.

Copyright: () 2020 by the authors. Licensee MDPI, Basel, Switzerland. This article is an open access article distributed under the terms and conditions of the Creative Commons Attribution (CC BY) license (https: / / creativecommons.org/ licenses/by/4.0/).

\begin{abstract}
We have developed an appropriate Computational Fluid Dynamics (CFD) model for assessing the exposure to risk of tunnel users during their evacuation process in the event of fire. The effects on escaping users, which can be caused by fire from different types of vehicles located in various longitudinal positions within a one-way tunnel with natural ventilation only and length less than $1 \mathrm{~km}$ are shown. Simulated fires, in terms of maximum Heat Release Rate (HRR) are: 8, 30, 50 , and $100 \mathrm{MW}$ for two cars, a bus, and two types of Heavy Goods Vehicles (HGVs), respectively. With reference to environmental conditions (i.e., temperatures, radiant heat fluxes, visibility distances, and $\mathrm{CO}$ and $\mathrm{CO}_{2}$ concentrations) along the evacuation path, the results prove that these are always within the limits acceptable for user safety. The exposure to toxic gases and heat also confirms that the tunnel users can safely evacuate. The evacuation time was found to be higher when fire was related to the bus, which is due to a major pre-movement time required for leaving the vehicle. The findings show that mechanical ventilation is not necessary in the case of the tunnel investigated. It is to be emphasized that our modeling might represent a reference in investigating the effects of natural ventilation in tunnels.
\end{abstract}

Keywords: risk analysis; computational fluid dynamics; road tunnels; natural ventilation; user safety

\section{Introduction}

Tunnel traffic accidents are rarer than on open roads [1,2]; however, their consequences might be more severe in terms of injuries and/or fatalities [3]. Tunnel fires are less frequent than tunnel traffic accidents, but when these occur in closed spaces such as tunnels all users might be involved and not only those directly affected by traffic collisions; in addition, major negative consequences might be expected [4]. In fact, a significant part of the tunnel could quickly fill up with hot gases, smoke, and/or toxic substances. Moreover, these hazardous conditions for user health might arise within a few minutes. Therefore, it is extremely important for user to begin the evacuation process from tunnels as soon as possible. In this respect, it is also necessary that tunnels are equipped with adequate safety systems that work properly [5-8].

Safety within road tunnels in the event of a fire, depends on many mutually dependent factors: Heat Release Rate (HRR), location of the burning vehicle, unidirectional or bidirectional traffic, vehicle queues, tunnel geometry, and safety systems of the tunnel. Certain human behaviors of users (e.g., anxiety, panic, speed of decision-making, and walking speed) can also affect self-evacuation.

Risk analysis is a very important tool that can be used for investigating the safety level of tunnels. In this regard, the European Directive 2004/54/EC [9]-which is applicable to tunnels of the Trans-European Road Network (TERN) with lengths (L) over $500 \mathrm{~m}-$ requires, when a tunnel is opened to the transit of dangerous goods, that a specific risk analysis should be made. The Italian Ministry of Infrastructure and Transports adopted the mentioned Directive in 2006 [10]. At the present time, in Italy, there are no particular 
restrictions to the passage of vehicles carrying dangerous goods (DGVs) through road tunnels. As a result, tunnels are to be considered free for the transit of all types of vehicles. Therefore, risk analyses are required for tunnels of the TERN with $\mathrm{L} \geq 500 \mathrm{~m}$.

There are several methods for performing risk analysis; however, an analysis based on Computational Fluid Dynamics (CFD) models appears to be the most suitable. CFD modeling can achieve a high level of accuracy by considering the mutual interaction of all the aforementioned factors, which affect user safety in tunnels in the case of fire. By using CFD models, studies available in the literature have prevalently investigated the efficiency of specific safety measures in tunnels such as, in particular, mechanical ventilation. However, in compliance with the European Directive 2004/54/EC, mechanical ventilation is required only for tunnels with lengths over $1000 \mathrm{~m}$. This means that for tunnels with $500<\mathrm{L}<1000 \mathrm{~m}$, which are very common in Italy, safety conditions are affected by natural ventilation. Unfortunately, the effects of natural ventilation due to vehicle motion (piston effect) hardly appears to have been studied. Some comparisons between natural and mechanical ventilation can be found in McQuade-Jones and Bilson [11]. Also Chow et al. [12], Yu and Wei [13], and Zhang et al. [14] deal with the issue of natural ventilation in road tunnels, but their studies are limited to the evaluation of the maximum temperatures and smoke back-layering length as a function of the tunnel slope, without any consideration about the evacuation process from the tunnel. Safety, under natural ventilation conditions of the tunnel in the event of a fire, is instead the main reason for justifying the present paper. Indeed, it is not clear whether natural ventilation is sufficient in all circumstances. This appears to represent a gap in our knowledge. Therefore, a risk analysis must be conducted.

In the light of the above considerations, the main objective of the present paper is to investigate the issue of natural ventilation in road tunnels in greater depth. This study may represent an advance in research for providing additional knowledge in the field of safety engineering, and to show whether further technical measures are still necessary to improve tunnel safety with natural ventilation only.

For this aim, among the CFD codes currently available for modeling fire scenarios, the Fire Dynamics Simulator (FDS) $[15,16]$ version 6.7 .3 was used. FDS, with associated Evac code (version 2.5.2. [17]) for simulating the evacuation process, was set up for a specific road tunnel. The tunnel investigated is within the field of applicability of the European Directive. It is $850 \mathrm{~m}$ long, presents an emergency exit at half-way, and is characterized by unidirectional traffic. A set of different positions of various burning vehicles within the tunnel, under specified traffic and geometry conditions, were investigated to provide additional knowledge on the effects of natural ventilation on tunnel safety.

The paper is organized as follows: the next section contains a literature review concerning risk analyses based on CFD models and evacuation processes from tunnels. Effects of safety measures for reducing the risk level in tunnels are also commented on. Then the FDS+Evac modeling developed in the present paper is described. Subsequently the results related to natural ventilation of the tunnel investigated are presented and discussed, and appropriate comparisons are made. Finally, comments for practical applications, conclusions and addresses for additional research are made.

\section{Literature Review}

Risk analysis based on CFD models is the most used tool for assessing the safety level of a tunnel in the event of a fire. In this respect, several studies have been carried out to evaluate the effects of some fire mitigation systems such as, in particular, ventilation within the tunnel.

Caliendo et al. [18] evaluated the effects of the longitudinal ventilation provided by jet-fans in a curved bidirectional road tunnel. Using the fire simulation ANSYS CFX code coupled with the STEPS (Simulation of Transient Evacuation and Pedestrian movementS) software for the evacuation process, they showed the effects of temperature, smoke, and toxic substances concentration on occupants during their escape from the tunnel. Due to 
the combined effect of mechanical ventilation and tunnel geometry, the major risk was found to be when the burning vehicle is in the middle of the tunnel.

Caliendo et al. [19] have subsequently extended their previous study to several fire scenarios due to different types of burning vehicles within the tunnel. The major risk level was found to be when the petrol tanker burns, and the tunnel is full of vehicles.

Xiaobo et al. [20], by using the results of the FDS, proposed a methodology for estimating the number of people at risk due to toxic substances caused by fire in road tunnels. The tunnel was assumed to be mechanically ventilated within 2 min after the start of the fire.

Chen et al. [21], by means of the FDS tool for simulating fire in tunnel, investigated the smoke flow layering length as a function of the longitudinal ventilation and point extraction.

Valasek and Glasa [22] used the FDS+Evac for simulating fire scenarios and user evacuation from a short two-lane road tunnel. The emergency mechanical ventilation system was assumed to be activated within $1 \mathrm{~min}$ after the start of the fire. They found that when the number of people trapped increased, most of the occupants used the exit portal rather than the emergency exit.

Glasa et al. [23] also used the FDS+Evac for simulating fire and user escape from a tunnel, which is equipped with jet-fans for mechanical ventilation. In particular, they focused on the factors that affect the evacuation process, emergency exit visibility, effects of smoke, and presence of obstacles.

Chow et al. [24], by using FDS, carried out several numerical simulations to study the critical velocity of longitudinal ventilation required for preventing the back-layering phenomenon as a function of the HRR both in horizontal and tilted tunnels.

Kadlic and Mózer [25], by basing on the use of FDS+Evac, modeled fire scenarios in a unidirectional road tunnel equipped with longitudinal ventilation; showing, in particular, the movement of smoke during counterwind (i.e., wind in opposite direction to jet-fans). The aim was to underline the uncertainties in fire modeling process, which were due to input data and fire scenario design.

Bosco et al. [26], using FDS+Evac, investigated the influence of smoke distribution, queue formation, and tunnel geometry on the evacuation process in the event of a fire. The results were compared to the evacuation experiments carried out in a road tunnel, and a good agreement was obtained. They found that the evacuation time depends closely on the time needed for each vehicle to stop, which can be estimated by using an appropriate queue formation model.

Caliendo et al. [27], in keeping with their aforementioned studies and by continuing to use ANSYS CFX+STEPS, individualized the optimal distance from the emergency exits in a bidirectional tunnel equipped with jet-fans.

Jun et al. [28], by means of FDS, studied the effects of different velocities of longitudinal ventilation, as well as different tunnel widths and HRRs, on the propagation of smoke in tunnels.

A. Król and M. Król [29], using FDS, assessed the consequences on the evacuation process due to two different fires in a road tunnel. They accounted for different types of ventilation systems, delay in fire detection system, and traffic conditions.

Summing up, the above chronological literature review shows that many studies have investigated the effectiveness of mechanical ventilation, as well as other fire mitigation measures, but few of them focused on the effects of natural ventilation caused by the vehicles in motion (piston effect). The lack of knowledge related to the effects of natural ventilation on self-evacuation from tunnels in the event of fire represents for us a driving motivation to investigate the issue in greater depth in the present paper. 


\section{Materials and Methods}

\subsection{Tunnel Description}

In this study, a two-lane straight unidirectional tunnel is investigated. It is $850 \mathrm{~m}$ long and has a horseshoe-shaped cross-section with a total width of $9.5 \mathrm{~m}$ (i.e., two lanes of $3.5 \mathrm{~m}$, and two sidewalks). The maximum height is $6.8 \mathrm{~m}$, and the cross-section area is $55.2 \mathrm{~m}^{2}$. The tunnel is assumed to be flat with no emergency lanes. An emergency exit is in the middle of the tunnel length.

The investigated one-way tunnel is not equipped with a mechanical ventilation system. However, a pressure difference of $5 \mathrm{~Pa}$ [30] is assumed to be applied between the entrance portal (portal A) and the exit portal (portal B) to simulate natural ventilation due to the piston effect of vehicles in motion.

The tunnel walls are made of concrete and have a thickness of $0.4 \mathrm{~m}$. Specifically, for concrete is assumed that the thermal conductivity is $1.67 \mathrm{~W} / \mathrm{m} / \mathrm{K}$, the specific heat is $0.94 \mathrm{~kJ} / \mathrm{kg} / \mathrm{K}$, the density is $2585 \mathrm{~kg} / \mathrm{m}^{3}$, and the emissivity is 0.9 [31].

\subsection{Traffic Volume}

The traffic flow, which is expressed in terms of Annual Average Daily Traffic (AADT), is assumed to be 10,000 vehicles/day per lane, and the percentage of Heavy Goods Vehicles (HGVs) is about $25 \%$. However, our study is based on the peak hour of traffic volume (VHP). This was made since the effects of VHP, in contrast with AADT, are expected to be worse in the event of a fire in tunnel. The presence of much more vehicles, which act as obstacles in the tunnel, might significantly increase temperatures, radiant heat fluxes, and toxic gas concentration; which affects user safety. In this regard, a VHP of 1243 vehicles/hour per lane was computed.

\subsection{Fire Scenarios}

Four fire scenarios corresponding to different types of burning vehicles are considered (car, bus, and two HGVs). Each burning vehicle is assumed to be located along the tunnel in five different positions: $145 \mathrm{~m}, 280 \mathrm{~m}, 420 \mathrm{~m}, 570 \mathrm{~m}$, and $710 \mathrm{~m}$ from the entrance portal (i.e., portal A). Car, bus, and the two HGVs are schematized as parallelepipeds, whose dimensions (length $\times$ width $\times$ height) expressed in meters are: $6 \times 1.8 \times 1.5$, $12 \times 2.5 \times 2.9$, and $12 \times 2.5 \times 3.2$ for the car, bus, and HGVs, respectively. Fire scenarios for the mentioned vehicles are reported in Table 1, in terms of maximum HRR and time to reach the maximum HRR $\left(t_{\max }\right)$. Each fire curve considers a linear law for the fire growth phase, followed by a constant HRR phase. All fire simulations were carried out for a time ( $t$ ) equal to $10 \mathrm{~min}$ (i.e., $t \geq t_{\max }$ ). The yields of combustion products are assumed as listed in the mentioned Table $1[32,33]$.

Table 1. Heat release rate (HRR) and yields of combustion products.

\begin{tabular}{ccccc}
\hline & $\begin{array}{c}\text { HRR } \\
{[\mathbf{M W}]}\end{array}$ & $\begin{array}{c}\mathbf{t}_{\text {max }} \\
{[\mathbf{m i n}]}\end{array}$ & $\begin{array}{c}\mathbf{C O} \\
{[\mathbf{k g} / \mathbf{k g}]}\end{array}$ & $\begin{array}{c}\text { Soot } \\
{[\mathbf{k g} / \mathbf{k g}]}\end{array}$ \\
\hline Two cars & 8 & 5 & 0.084 & 0.08 \\
Bus & 30 & 9 & 0.1 & 0.05 \\
HGV & 50 & 10 & 0.15 & 0.025 \\
HGV & 100 & 10 & 0.15 & 0.025 \\
\hline
\end{tabular}

\section{CFD Modeling}

\subsection{Physical Modeling}

In CFD modeling, the main governing equations are the continuity equation, the momentum equation, and the energy equation. These equations, coupled to the submodels to describe the physical mechanisms of combustion, turbulence, and thermal radiation, are solved by the finite volume method. The results (temperature, velocity and direction of air flow, and smoke and toxic gas concentration) are obtained for each cell in 
which the tunnel volume is discretized, and their accuracy depends in particular on the fire scenario, physical models used, and mesh fineness.

In this study, FDS version 6.7.3 was used. It is an open source CFD model developed by the U.S. National Institute of Standards and Technology (NIST). FDS simulation tool is a fire-driven fluid flow model that has also been widely used in the literature for tunnel fire scenarios, and in which the Navier-Stokes equations are solved numerically. In this regard, the combustion, turbulence, and radiation models employed in FDS are described in detail in the FDS user guide [16]. In particular, for FDS application, the main input data, which were discussed in detail in Sections 3.1 and 3.3, concern tunnel geometry, longitudinal slope, location and geometry of the fire source, HRR, yields of combustion products, geometric characteristics of the vehicles in the queue, position of emergency exits, and pressure difference between tunnel portals.

\subsection{Model Validation}

We preliminary validated the FDS code by means of a comparison with the experimental data of temperatures related to a case of a small-scale fire, which is reported in Xue et al. [34]. We found a good level of conformity between the simulation results and the temperatures measured (an error of no more than $5 \%$ ).

\subsection{Grid Sensitivity Analysis}

In a FDS application, the accuracy of the results and the calculation time depend above all on the mesh fineness. In this respect, the grid resolution is evaluated by the non-dimensional expression $\mathrm{D}^{*} / \delta_{\mathrm{x}}[16]$, in which $\delta_{\mathrm{x}}$ is the nominal size grid [m], while the characteristic length scale $\mathrm{D}^{*}[\mathrm{~m}]$ is expressed as follows:

$$
\mathrm{D}^{*}=\left(\frac{\mathrm{Q}}{\rho_{\infty} \mathrm{c}_{\mathrm{p}} \mathrm{T}_{\infty} \sqrt{\mathrm{g}}}\right)^{\frac{2}{5}}
$$

where $Q$ is the HRR $[W], \rho_{\infty}$ is the air density $\left[\mathrm{kg} / \mathrm{m}^{3}\right], \mathrm{c}_{\mathrm{p}}$ is the specific heat of the air $[\mathrm{J} / \mathrm{kg} / \mathrm{K}], \mathrm{T}_{\infty}$ is the ambient temperature $[\mathrm{K}]$, and $\mathrm{g}$ is the gravity acceleration $\left[\mathrm{m} / \mathrm{s}^{2}\right]$. According to the FDS user guide [16], an adequate resolution is obtained when $\mathrm{D}^{*} / \delta_{\mathrm{x}}$ is between 4 and 16 . In this regard, it was found that: $\mathrm{D}^{*}=2.21$ for two cars, $\mathrm{D}^{*}=3.75$ for bus, $\mathrm{D}^{*}=4.60$ for HGV (50 MW), and $\mathrm{D}^{*}=6.07$ for HGV (100 MW). Therefore, for each scenario investigated, the size of the cell side should be in the range of $0.14-0.55 \mathrm{~m}$ for two cars, $0.23-0.94 \mathrm{~m}$ for bus, $0.29-1.15 \mathrm{~m}$ for HGV (50 MW), and 0.38-1.52 $\mathrm{m}$ for HGV (100 MW). It is to be said that only parallelepiped cells (preferably cubic) can be employed in the FDS.

In Table 2 are reported the results of the grid sensitivity analysis in terms of temperature as a function of the cell size. These outcomes are related to points located at the tunnel ceiling; in particular, at a height of $5.5 \mathrm{~m}$ from the road pavement, and longitudinal distances equal to $10 \mathrm{~m}$ both downstream and upstream from the fire center.

Table 2. Grid sensitivity analysis: temperature values at driving lane center $5.5 \mathrm{~m}$ from the road pavement.

\begin{tabular}{|c|c|c|c|c|}
\hline \multirow{3}{*}{$\begin{array}{l}\text { Cell Size } \\
\text { [m] }\end{array}$} & \multicolumn{4}{|c|}{ Temperature Values $5.5 \mathrm{~m}$ from the Road Pavement } \\
\hline & \multicolumn{2}{|c|}{ Cross-Section $-10 \mathrm{~m}$} & \multicolumn{2}{|c|}{ Cross-Section $+10 \mathrm{~m}$} \\
\hline & $\begin{array}{c}\mathrm{T} \\
{\left[{ }^{\circ} \mathrm{C}\right]}\end{array}$ & $\begin{array}{c}\text { Error } \\
{[\%]}\end{array}$ & $\begin{array}{c}\mathrm{T} \\
{\left[{ }^{\circ} \mathrm{C}\right]}\end{array}$ & $\begin{array}{c}\text { Error } \\
{[\%]}\end{array}$ \\
\hline 0.2 & 588 & - & 754 & - \\
\hline 0.4 & 583 & 0.85 & 751 & 0.40 \\
\hline 0.5 & 567 & 3.57 & 739 & 2.39 \\
\hline 0.8 & 484 & 17.69 & 703 & 6.76 \\
\hline 1.0 & 449 & 23.64 & 674 & 10.61 \\
\hline
\end{tabular}


From Table 2 one can see that the cell size smaller than $0.4 \mathrm{~m}$ did not provide significant differences in temperature predictions. In fact, the percentage errors between the temperature values were found to be with cells size of $0.4 \mathrm{~m}$ and $0.2 \mathrm{~m}$ less than $1 \%$. Since the computation time increases as the mesh becomes finer, the tunnel volume is assumed to be divided into cubic cells of $0.4 \mathrm{~m}$ side in the present paper. A total number of 1,095,255 cells were used in our study.

Figure 1 provides a view of the tunnel simulated by means of FDS.

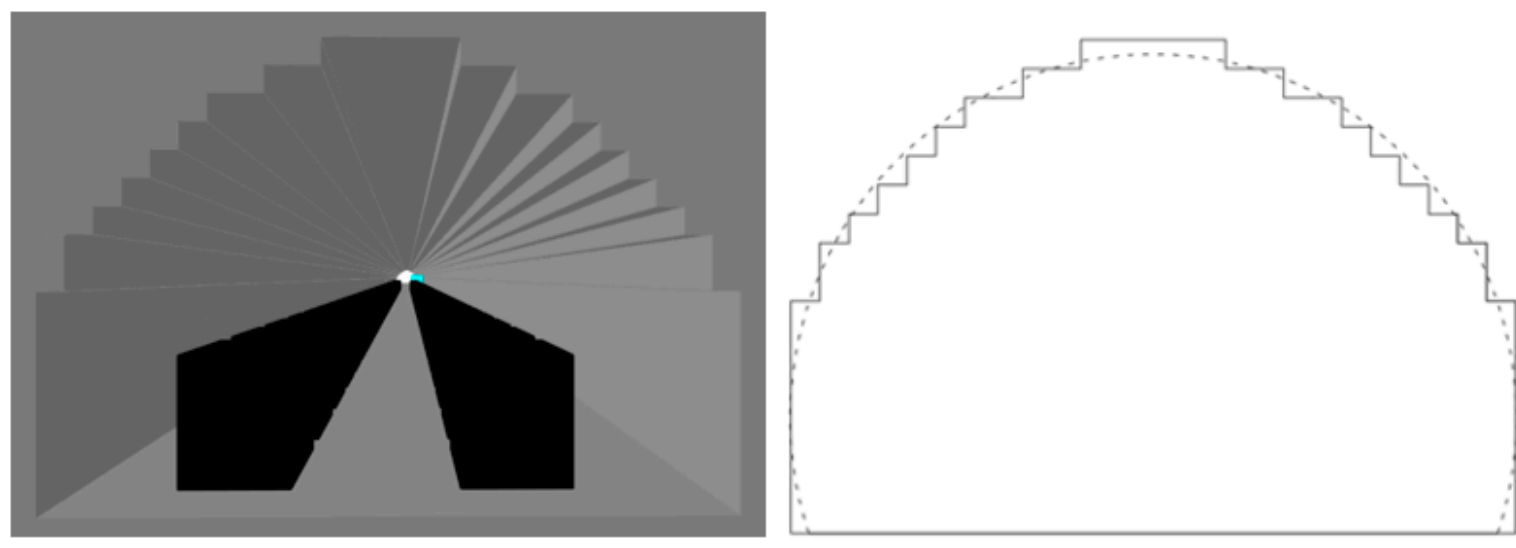

Figure 1. View of the tunnel simulated by means of FDS.

\section{Evacuation Modeling}

\subsection{Simulation Settings}

In the present paper, the agent-based egress calculation module of FDS, called Evac [17], is used to model the user evacuation process from the tunnel. The mentioned behavior model treats each evacuee as an individual agent (i.e., user in our case) with different characteristics and escape strategies. Users can move in a two-dimensional horizontal field, and the environmental conditions within the tunnel play a key role in reducing both the walking speed of users and the choice of exit. In particular, the effects of the concentration of $\mathrm{O}_{2}, \mathrm{CO}_{2}, \mathrm{CO}$, etc., are used by the model to calculate the Fractional Effective Dose $\left(\mathrm{FED}_{\text {toxic gases }}\right)$, which can influence the users' evacuation.

The main input data of the evacuation model, which will be discussed in detail in Sections 5.2 and 5.3, concern initial position of users in tunnel at the start of fire, number of users within each vehicle in queue, the user pre-movement time, walking speed, and escape direction.

However, it is to be said that the effects of temperature and radiation on evacuation are not yet taken into account by Evac. For this reason, an additional procedure has been used in the present paper to also calculate the Fractional Effective Dose (FED) due to both the heat and radiant heat flux exposure (i.e., $\mathrm{FED}_{\text {heat }}$ ).

\subsection{Queue Formation and Egress Model}

Based on the HRR and the positions of the fire source along the tunnel, different FDS+Evac simulations were performed. In the case of unidirectional traffic flow, the number of vehicles in the queue upstream of the fire was estimated assuming that: (i) queued vehicles stop without overtaking the burning vehicle; (ii) the vehicles queue up filling both lanes; (iii) the first vehicle in the queue is located at $10 \mathrm{~m}$ from the posterior surface of the burning vehicle; (iv) each vehicle maintains a safety distance of $2 \mathrm{~m}$ from the preceding vehicle in the queue. According to these assumptions, when the burning vehicle is at $145 \mathrm{~m}$ from the entrance portal (i.e., portal A), the traffic queue is formed by 32 vehicles, 66 vehicles when the burning vehicle is at $280 \mathrm{~m}$ from portal A, 100 vehicles when the burning vehicle is at $420 \mathrm{~m}$ from portal $\mathrm{A}, 138$ vehicles when the burning vehicle is at $570 \mathrm{~m}$ from portal $\mathrm{A}$, and 174 vehicles when the burning vehicle is at $710 \mathrm{~m}$ from 
portal A. Figure 2 represents a schematic layout of queued vehicles upstream of the fire source for the one-way tunnel investigated.

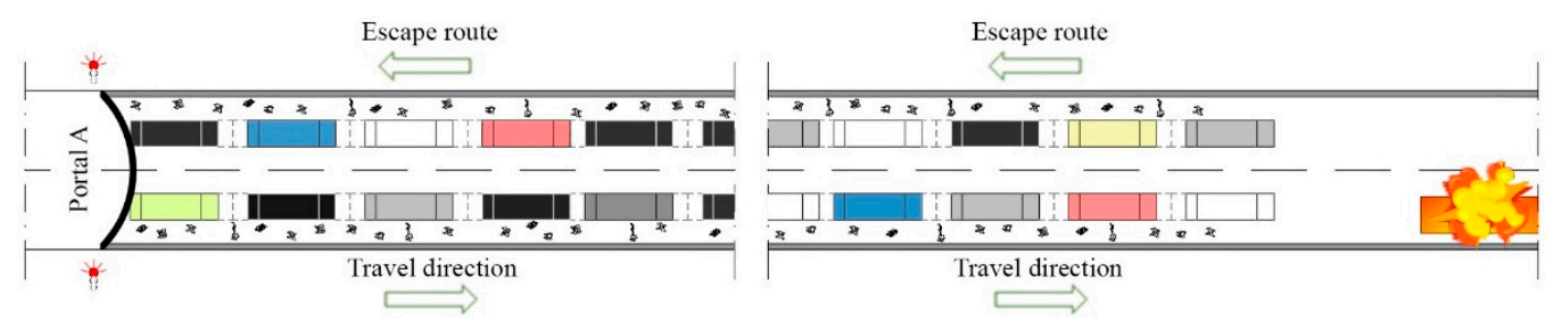

Figure 2. Schematic layout of queued vehicles upstream of the fire source.

The number of users potentially at risk within the tunnel (i.e., the number of people trapped upstream from the burning vehicle) depends on the number of cars, HGVs, and buses in the queue, and the number of people present in each type of vehicle. In this respect, the occupancy rate of cars, HGVs, and buses were assumed to be equal to 1.7 [27], 1, and 30 people, respectively. The average occupancy rate considering all vehicles in the queue (i.e., including cars, buses, and HGVs) was computed to be equal to about 2.1. Obviously, by multiplying the aforementioned number of queuing vehicles by 2.1 , we estimated the following number of people escaping upstream of the fire: $68,139,211,291$, and 367 users when the burning vehicle is located at $145 \mathrm{~m}, 280 \mathrm{~m}, 420 \mathrm{~m}, 570 \mathrm{~m}$, and $710 \mathrm{~m}$, respectively.

The initial position of each user that starts to walk for reaching a safe place, at the moment of fire starting or during the fire growth phase, is assumed to be next to his own vehicle.

It was also assumed, when the burning vehicle is located at $145 \mathrm{~m}, 280 \mathrm{~m}$, and $420 \mathrm{~m}$, that all users (evacuee) evacuate from the entrance portal (i.e., portal A). Instead, when the burning vehicle is located at $570 \mathrm{~m}$ and $710 \mathrm{~m}$ from (the) entrance portal A, escaping users use both the mentioned portal A and the emergency exit located in the middle of the tunnel length. Table 3 shows the total number of escaping users in the direction of (the) portal A and emergency exit, respectively.

Table 3. Number of people escaping from portal A and emergency exit.

\begin{tabular}{ccc}
\hline Fire Location & \multicolumn{2}{c}{ Number of People Escaping from: } \\
\cline { 2 - 3 } (Distance from Portal A) & Portal A & Emergency Exit \\
\hline $145 \mathrm{~m}$ & 68 & - \\
$280 \mathrm{~m}$ & 139 & - \\
$420 \mathrm{~m}$ & 211 & - \\
$570 \mathrm{~m}$ & 168 & 123 \\
$710 \mathrm{~m}$ & 168 & 199 \\
\hline
\end{tabular}

\subsection{Evaluation of RSET and ASET}

The evacuation process is generally investigated by comparing the Available Safe Egress Time (ASET) and the Required Safe Egress Time (RSET). In particular, ASET represents the time required to exceed the tenability criteria after the fire has occurred, whereas RSET is the time within which each occupant reaches a safe place. Thanks to the combination of the FDS and its evacuation module (Evac), the ASETs of each user within the tunnel and the RSETs can be determined.

ASET can be estimated using the aforementioned FED. In this respect, both the toxic effects of gaseous fire products ( $\left.\mathrm{FED}_{\text {toxic gases }}\right)$ and the exposure of people to heat and radiant heat flux ( $\left.\mathrm{FED}_{\text {heat }}\right)$ should be taken into account. According to the FED concept, a user is considered to be incapacitated when at least one of $F E D_{\text {toxic gases }}$ and FED heat exceeds unity [35]. The $\mathrm{FED}_{\text {toxic gases }}$ value for each escaping user is automatically 
calculated by the FDS model as a combination of different toxic gas concentrations as follows [17]:

$$
\mathrm{FED}_{\text {toxic gases }}=\left(\mathrm{FED}_{\mathrm{CO}}+\mathrm{FED}_{\mathrm{CN}}+\mathrm{FED}_{\mathrm{NO}_{\mathrm{x}}}+\mathrm{FLD}_{\text {irr }}\right) \cdot \mathrm{HV}_{\mathrm{CO}_{2}}+\mathrm{FED}_{\mathrm{O}_{2}} \text {, }
$$

where $\mathrm{FED}_{\mathrm{CO}}$ is the fraction of an incapacitating dose of $\mathrm{CO}, \mathrm{FED}_{\mathrm{CN}}$ is the fraction of an incapacitating dose of $\mathrm{CN}, \mathrm{FED}_{\mathrm{NO}_{\mathrm{x}}}$ is the fraction of an incapacitating dose of $\mathrm{NO}_{\mathrm{x}}, \mathrm{FLD}_{\text {irr }}$ is the fraction lethal dose of irritants, $\mathrm{HV}_{\mathrm{CO}_{2}}$ is the hyperventilation factor induced by carbon dioxide, and $\mathrm{FED}_{\mathrm{O}_{2}}$ is the fraction of an incapacitating dose of low $\mathrm{O}_{2}$ hypoxia. Each $F E D_{\text {toxic gases }}$ value is computed as the integral from zero to the time $\left(t_{i}\right)$ needed by the user to reach a safe place.

The $\mathrm{FED}_{\text {heat }}$ value due to both the heat and radiant heat flux exposure has been calculated as follows [35]:

$$
\mathrm{FED}_{\text {heat }}=\sum_{\mathrm{t}_{1}}^{\mathrm{t}_{2}}\left(\frac{1}{\mathrm{t}_{\text {Irad }}}+\frac{1}{\mathrm{t}_{\text {Iconv }}}\right) \Delta \mathrm{t}
$$

where $t_{\text {Irad }}=16.67 / q^{1.33}$ is the time in minutes to incapacitation due to a radiant heat flux $q$ in $\mathrm{kW} / \mathrm{m}^{2}$, and $\mathrm{t}_{\mathrm{Iconv}}=5 \cdot 10^{7} \cdot T^{-3.4}$ is the time in minutes to incapacitation due to a temperature $\mathrm{T}$ in ${ }^{\circ} \mathrm{C}$. An automatic procedure, based on Visual Basic for Applications (VBA) code, was developed in this paper for estimating the FED heat every time step of the simulation, which was set equal to $2 \mathrm{~s}$. Both temperature and radiant heat flux were measured at $2 \mathrm{~m}$ above the road pavement along the escape routes (sidewalks) upstream of the burning vehicle.

RSET includes three-time components: (i) vehicle queuing time; (ii) the detection and reaction time (i.e., the pre-movement time); (iii) the user movement time.

The pre-movement time was assumed to be $90 \mathrm{~s}$ in the event of 8, 50, and $100 \mathrm{MW}$ fire; while it increased by $60 \mathrm{~s}$ (for a total of $150 \mathrm{~s}$ ) for the $30 \mathrm{MW}$ fire to take into account the time needed for all occupants to leave the bus [36]. Although the vehicles into the tunnel are assumed to be stationary when the fire started, the arrival time of every vehicle was taken into account by assigning an extra pre-movement time to each user.

The user movement time depends in particular on the user walking speed [5]. In this study, the unimpeded walking speed was assumed to be $0.7 \mathrm{~m} / \mathrm{s}$. However, the effective walking speed is likely to be lower during a fire due to the presence of obstacles (e.g., vehicles in the queue), reduced visibility, and very high concentrations of smoke, irritating and toxic gases along the escape routes. These effects on user walking speed are taken into account by the Evac code, which uses as input the FDS output.

\section{Acceptable Safety Criteria}

With reference to the risk that fire poses to the tunnel user life, traditionally there are two ways of verifying the tenable conditions along the evacuation path. The first is based on the values of temperature, radiation heat flux, concentration of toxic gases $\left(\mathrm{CO}, \mathrm{CO}_{2}\right)$, and visibility distance. The second, instead, involves the FED. In the present paper, we use both. In Table 4 are reported the acceptance safety criteria that we have used as benchmarks. 
Table 4. Acceptable safety criteria for tunnel users in the event of a fire.

\begin{tabular}{ccc}
\hline Parameter & Criterion & Reference \\
\hline Temperature & $\leq 60{ }^{\circ} \mathrm{C}$ & {$[37]$} \\
Radiant heat flux & $\leq 2-2.5 \mathrm{~kW} / \mathrm{m}^{2}$ & {$[37]$} \\
Carbon monoxide & $\leq 1200 \mathrm{ppm}$ & {$[38]$} \\
Carbon dioxide & $\leq 40,000 \mathrm{ppm}$ & {$[38]$} \\
Visibility distance & $\geq 10 \mathrm{~m}$ & {$[37]$} \\
\hline FED $_{\text {toxic gases }}$ & $<1$ & {$[35]$} \\
FED heat & $<1$ & {$[35]$} \\
\hline
\end{tabular}

\section{Analysis of Results}

\subsection{Longitudinal Profiles}

To assess whether people can safely evacuate from the tunnel (i.e., upstream of the fire in direction of portal A), the longitudinal profiles of temperature, radiative heat flux, toxic gases, and visibility distance predicted at breathing height $(2 \mathrm{~m})$ along the escape path, after $10 \mathrm{~min}$ from the fire start, are reported below. These values were compared with the corresponding tenability limits for the survival of tunnel users in case of fire. However, for giving also more complete information, it is to be said that as a result of natural ventilation, which pushes the fire-induced threats towards portal B, the worst environmental conditions occur downstream from the burning vehicle. However, this is not of interest in this specific case of one-way tunnels since people evacuate upstream of the fire.

\subsubsection{Temperatures}

Figure 3 shows the longitudinal temperature profiles after $10 \mathrm{~min}$ from the start of the fire and at a height of $2 \mathrm{~m}$ along the escape path. The burning vehicle is assumed to be, in this case, in the middle of the tunnel length. With reference to a pre-movement time of both $90 \mathrm{~s}$ and $150 \mathrm{~s}$ (only for the bus), Figure 3 shows the positions occupied by the last user, which is escaping from the tunnel in direction of portal A, after a time $t=10 \mathrm{~min}$ from the start of the fire. One may note that the above-mentioned user is at a distance of $47 \mathrm{~m}$ from portal A (i.e., $378 \mathrm{~m}$ from fire) in the event of 8, 50, and $100 \mathrm{MW}$ fire (red user), and $89 \mathrm{~m}$ (i.e., $336 \mathrm{~m}$ from the fire) in the event of $30 \mathrm{MW}$ fire (green user). Figure 3 shows that temperatures higher than $60^{\circ} \mathrm{C}$ are observed only for a distance from the fire of: $5 \mathrm{~m}, 30 \mathrm{~m}$, $50 \mathrm{~m}$, and $170 \mathrm{~m}$ in the case of $8 \mathrm{MW}, 30 \mathrm{MW}, 50 \mathrm{MW}$, and $100 \mathrm{MW}$ fires, respectively. This means that also the last user escaping is safe since he/she is exposed during the evacuation to temperatures lower than the tenability limit of $60^{\circ} \mathrm{C}$ [37].

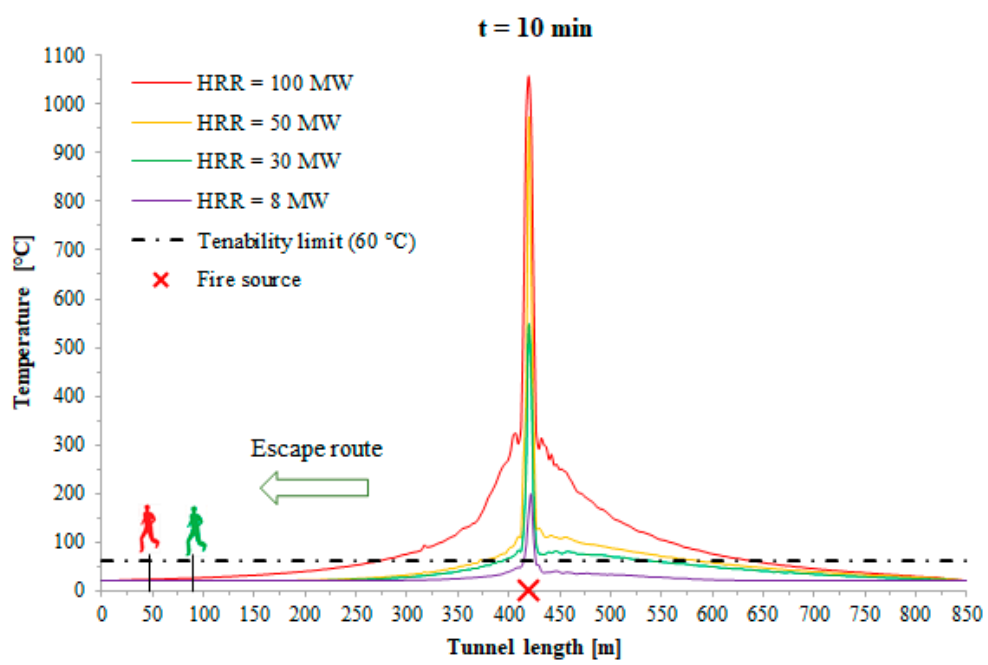

Figure 3. Longitudinal temperature profiles $(t=10 \mathrm{~min})$ at a height of $2 \mathrm{~m}$ along the escape path when the fire source is in the middle of the tunnel length. 


\subsubsection{Radiant Heat Flux}

Figure 4 reports the longitudinal radiant heat flux profiles after $10 \mathrm{~min}$ from the start of the fire and at a height of $2 \mathrm{~m}$ along the escape path. Figure 4 shows, in particular, that the last user escaping from the tunnel in direction of portal $\mathrm{A}$ is exposed to a radiant heat flux value $\leq 2 \mathrm{~kW} / \mathrm{m}^{2}$ [37].

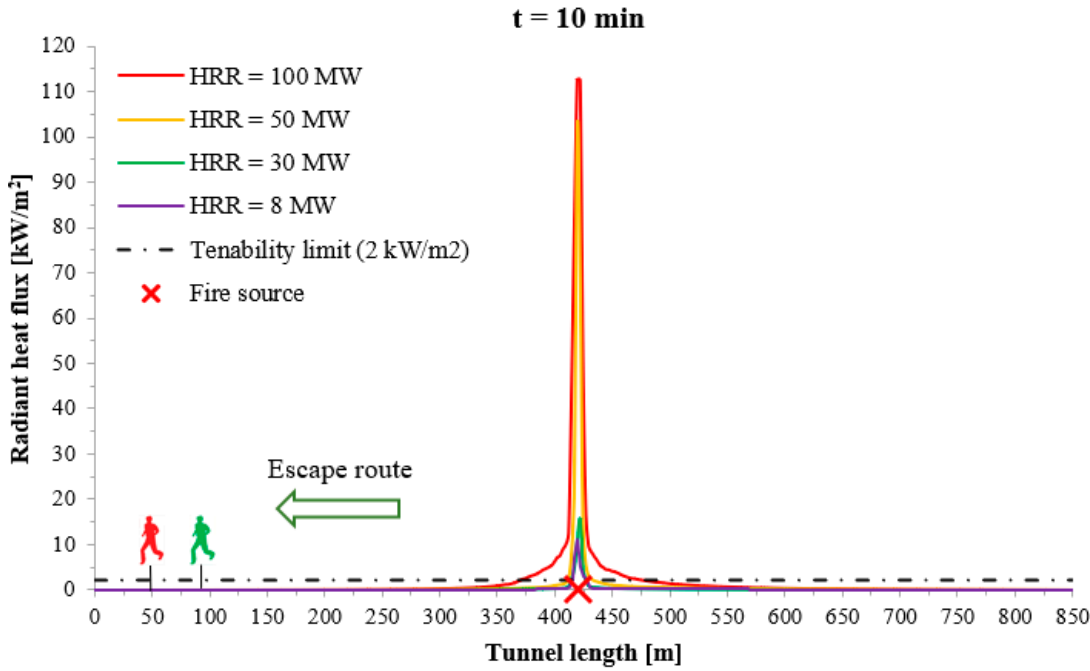

Figure 4. Longitudinal radiant heat flux profiles $(t=10 \mathrm{~min})$ at a height of $2 \mathrm{~m}$ along the escape path when the fire source is in the middle of the tunnel length.

\subsubsection{Toxic Gases}

Figures 5 and 6 report, respectively, the longitudinal profiles of $\mathrm{CO}$ and $\mathrm{CO}_{2}$ concentration after $10 \mathrm{~min}$ from the start of the fire and at a height of $2 \mathrm{~m}$ along the escape path. Figures 5 and 6 show that the last user escaping from the tunnel in direction of portal $\mathrm{A}$ is also exposed to $\mathrm{CO}$ and $\mathrm{CO}_{2}$ concentrations lower than the tenability limits of 1200 and 40,000 ppm, respectively [38].

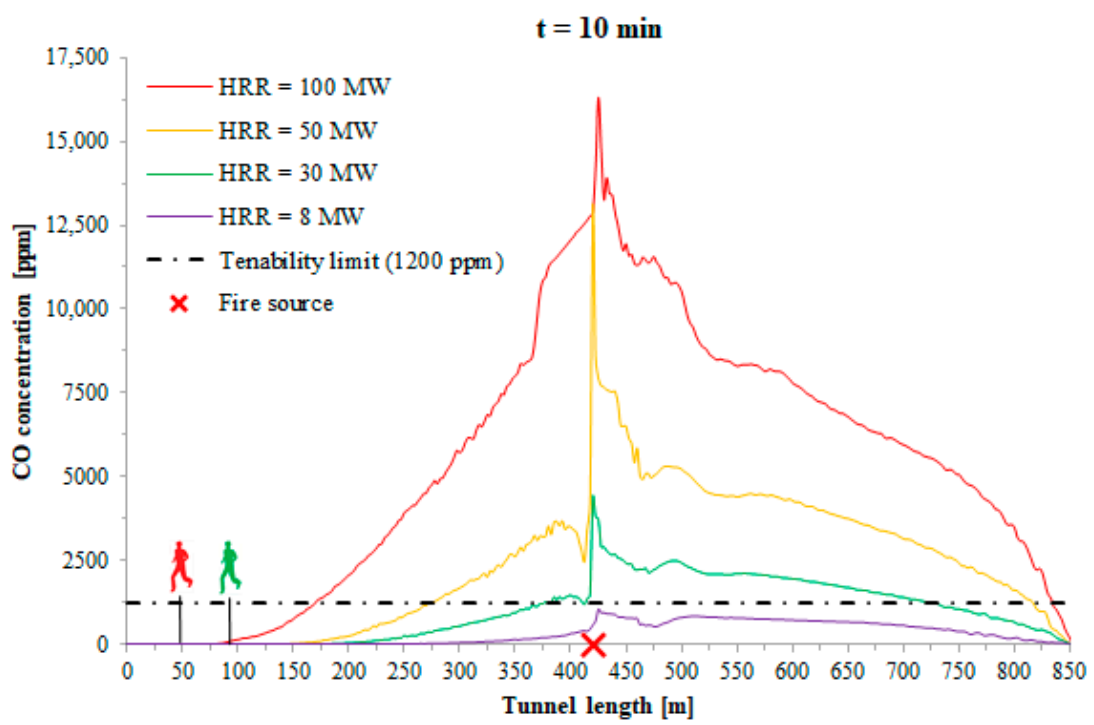

Figure 5. Longitudinal $\mathrm{CO}$ concentration profiles $(\mathrm{t}=10 \mathrm{~min})$ at a height of 2 along the escape path when the fire source is in the middle of the tunnel length. 


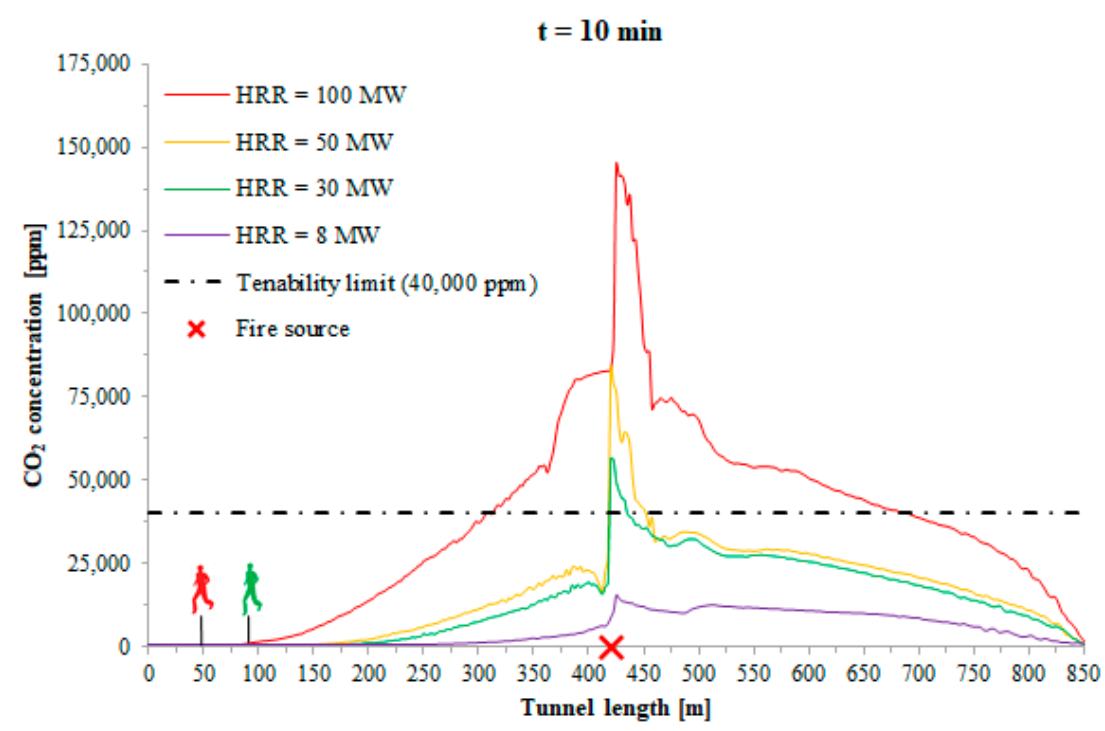

Figure 6. Longitudinal $\mathrm{CO}_{2}$ concentration profiles $(t=10 \mathrm{~min})$ at a height of $2 \mathrm{~m}$ along the escape path when the fire source is in the middle of tunnel length.

\subsubsection{Visibility Distance}

The production and spread of smoke along the evacuation path might limit the visibility of users in the tunnel during their evacuation process, and consequently reduce their walking speed. In Figure 7 are reported the longitudinal visibility distance profiles after $10 \mathrm{~min}$ from the start of the fire and at a height of $2 \mathrm{~m}$ along the escape path. Figure 7 shows that the last user escaping from the tunnel in direction of portal A has also a visibility higher than the tenability limit of $10 \mathrm{~m}$ [37].

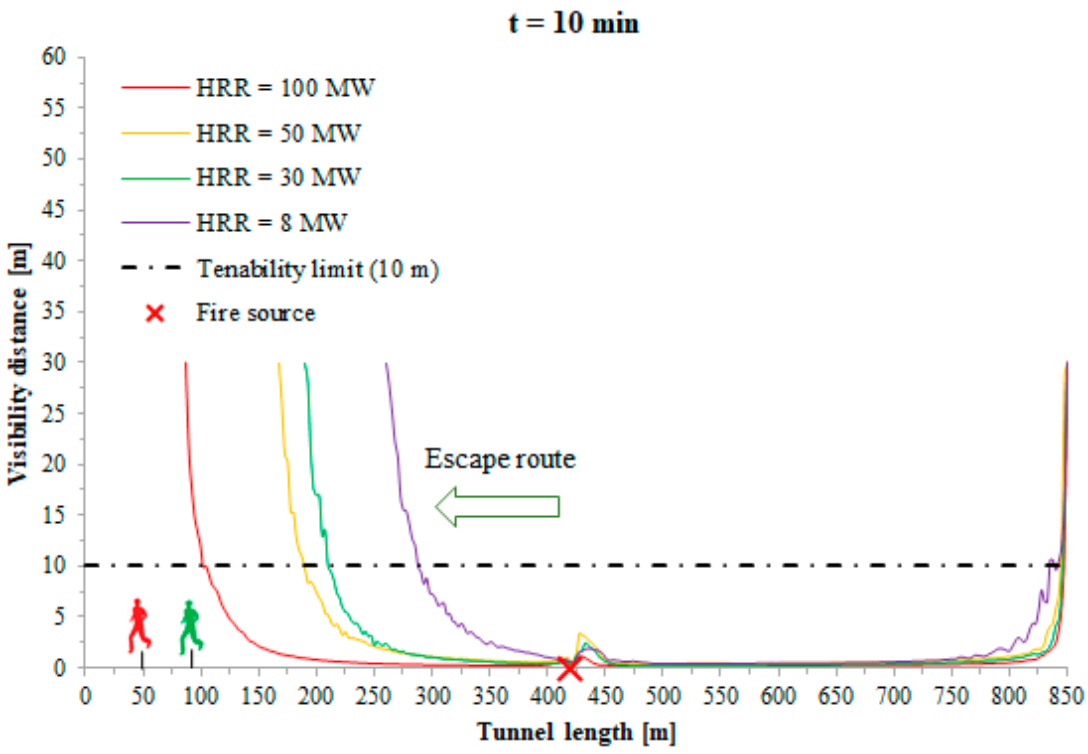

Figure 7. Longitudinal visibility distance profiles $(t=10 \mathrm{~min})$ at a height of $2 \mathrm{~m}$ along the escape path when the fire source is in the middle of tunnel length.

It is to be stressed that all the aforementioned safe evacuation conditions were found also after $5 \mathrm{~min}$ from the start of the fire, as well as for the remaining four longitudinal positions of the fire in the tunnel investigated. The results are not reported here to save space. 


\subsection{FED Results of the FDS Simulations and RSET}

The maximum FED toxic gases were taken from Evac simulations, whereas the maximum FED heat was taken by using the mentioned Equation (3). To be considered an acceptable result, all FED values due to both toxic gases and heat must be below 1 . Table 5 summarized the outcomes obtained with reference to the burning vehicle in the middle of the tunnel length.

Table 5. FED results at a height of $2 \mathrm{~m}$ along the escape path when the fire is in the middle of tunnel length.

\begin{tabular}{|c|c|c|c|}
\hline $\begin{array}{l}\text { HRR } \\
{[\mathrm{MW}]}\end{array}$ & $\begin{array}{l}\text { Maximum Evacuation Time in the Event of Fire } \\
\text { [min] }\end{array}$ & Max FED $_{\text {toxic gases }}$ & Max FED heat \\
\hline 8 & 11 & 0.003 & 0.007 \\
\hline 30 & 12 & 0.333 & 0.020 \\
\hline 50 & 11 & 0.010 & 0.019 \\
\hline 100 & 11 & 0.022 & 0.029 \\
\hline
\end{tabular}

One may note that both $\mathrm{FED}_{\text {toxic gases }}$ and $\mathrm{FED}_{\text {heat }}$ are $<1$. FED results less than 1 were found also for the remaining four longitudinal positions of the fire in the tunnel investigated.

However, the results of the evacuation process, when they are presented in a graphic form by using the cumulative distributions of RSET, may also provide additional information. Figure $8 \mathrm{a}-\mathrm{d}$, for example, apart from showing that with the fire located in the middle of the tunnel length the maximum evacuation times are those reported in Table 5, indicates that the 50th percentile of the evacuation time (i.e., that $50 \%$ of users are below that value) in the event of 8,50, and $100 \mathrm{MW}$ fire can range from $3.1 \mathrm{~min}$ (burning vehicle located at $145 \mathrm{~m}$ from portal A) to $6.4 \mathrm{~min}$ (burning vehicle in the middle of the tunnel length). Moreover, the 50th percentile of the evacuation time in the event of $30 \mathrm{MW}$ (i.e., bus fire) can range from 4.1 to $7.4 \mathrm{~min}$.
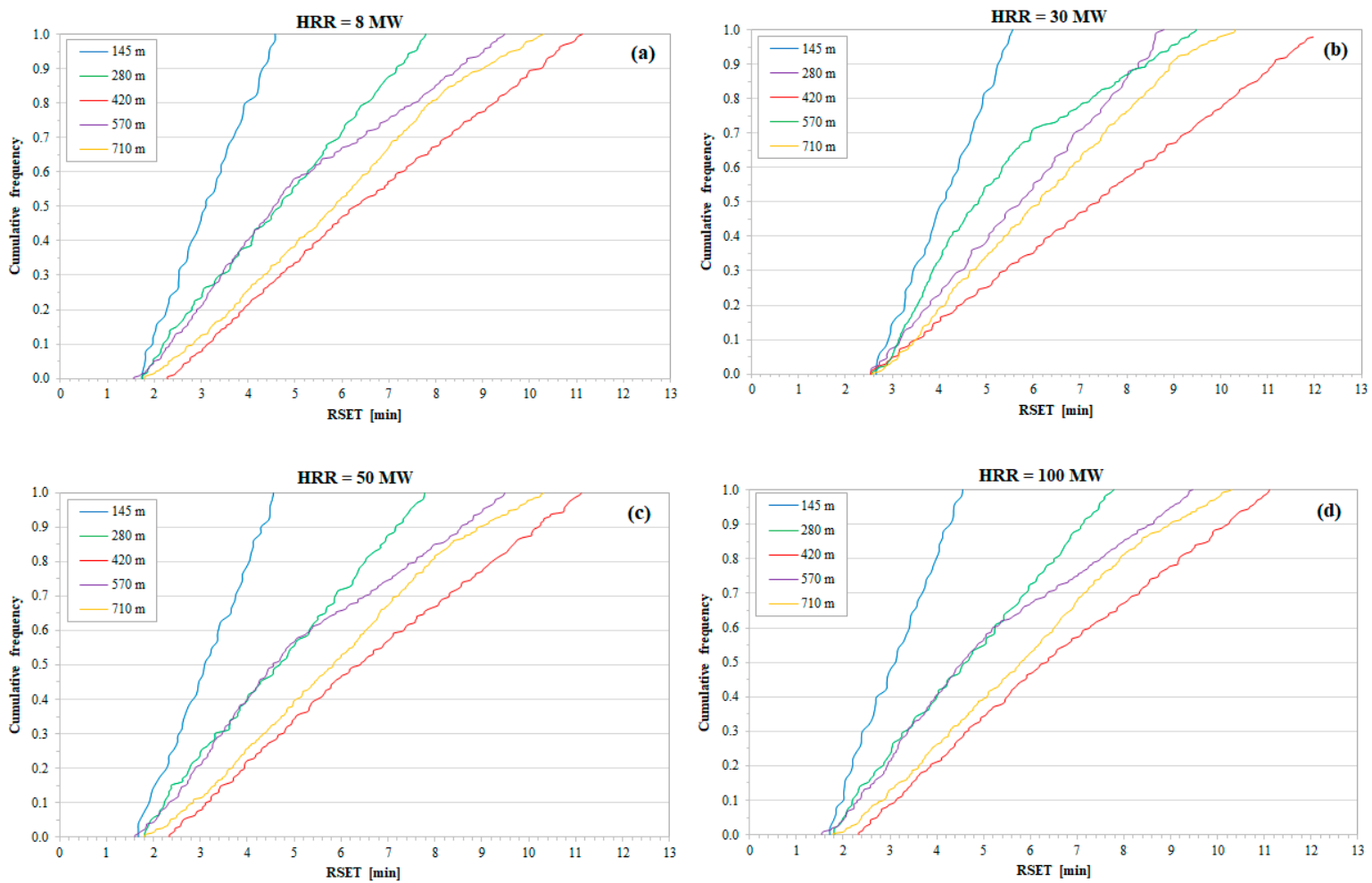

Figure 8. Cumulative frequency distributions of RSET in the event of: (a) 8 MW fire; (b) 30 MW fire; (c) 50 MW fire; (d) $100 \mathrm{MW}$ fire, and for the five different positions of fire within the tunnel investigated. 
Since the results have proved that escaping users are subjected to temperatures, radiant heat fluxes, and toxic gas concentrations lower than the tenability limits, as well as the fact

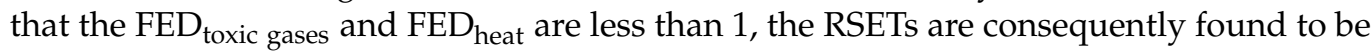
lower than the ASETs for each user. In other terms, for all fire scenarios simulated, users can reach a safe place (entrance portal or emergency exit) without safety issues during the evacuation process.

\subsection{Back-Layering Phenomenon and Smoke Stratification}

Figure 9 presents the back-layering phenomenon and smoke stratification along the tunnel investigated after $10 \mathrm{~min}$ from the start of the fire located in the middle of tunnel length.

(a)

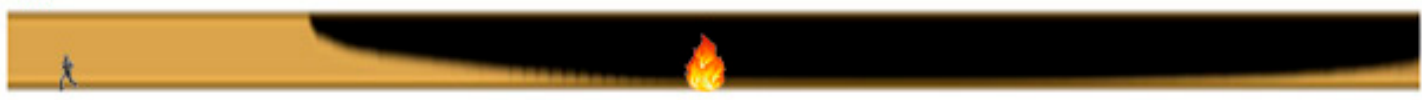

(b)

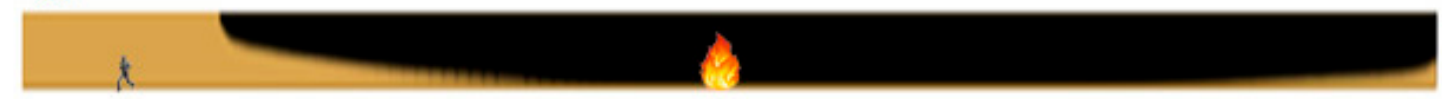

(c)

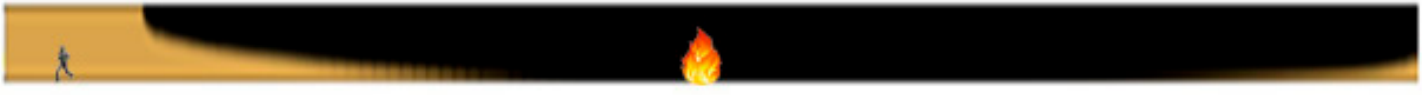

(d)

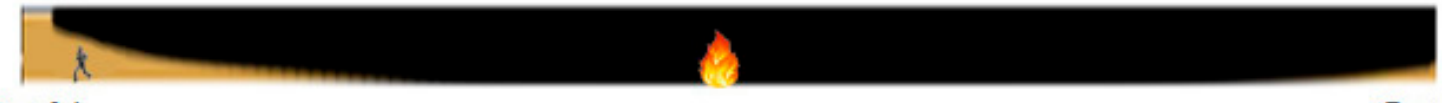

Portal A

Portal B

Figure 9. Contours of smoke propagation within the tunnel investigated, after $10 \mathrm{~min}$ from the start of fire, when the burning vehicle is in the middle of the tunnel length: (a) $8 \mathrm{MW}$; (b) $30 \mathrm{MW}$; (c) $50 \mathrm{MW}$; (d) $100 \mathrm{MW}$.

It can be observed that: (i) natural ventilation that pushes smoke towards portal B is not able to prevent the back-layering phenomenon (i.e., smoke moves against the air flow provided by natural ventilation); (ii) with the increase in the HRR, the length of back-layering phenomenon increases; (iii) the smoke stratification for the two directions upstream and downstream of the fire is not symmetrical due to natural ventilation; (iv) the worst conditions of smoke are found downstream of the fire.

However, even if the back-layering length upstream of the fire increases with the HRR, it has been found that the smoke extends along the tunnel ceiling up to 235, 295, 335, and $400 \mathrm{~m}$ from the fire center in the case of the $8,30,50$, and $100 \mathrm{MW}$, respectively. It is to be stressed that the position occupied by the last user, who is escaping from the tunnel in the direction of portal A, is not affected by the presence of smoke at his breathing height of $2 \mathrm{~m}$. This graphically confirms the safety conditions found in the previous paragraph for escaping users.

\section{Summary and Conclusions}

This research was motivated in particular by the need to develop a CFD modeling for simulating several fire scenarios in a one-way road tunnel with natural ventilation, and for assessing the exposure to risk of users during their evacuation process. To this aim, the FDS with the associated Evac code was set up, and then used for a tunnel with $\mathrm{L}<1 \mathrm{~km}$ for which mechanical ventilation is not required according to the European Directive 2004/54/EC.

Four fire scenarios corresponding to different types of burning vehicles were considered (car, bus, and two HGVs). Fire scenarios, in terms of maximum HRR, for the mentioned vehicles were assumed to be: 8, 30, 50, and $100 \mathrm{MW}$, respectively. Each burning 
vehicle was assumed to be located along the tunnel investigated in five different positions from the entrance portal.

The evacuation times were found to be higher when fire was related to a bus, which is due to a major pre-movement time needed so that the last person occupying the bus may also leave the vehicle. However, the results of the fluid dynamic analysis, interpreted in terms of environmental conditions along the evacuation path (i.e., temperatures, radiant heat fluxes, visibility distances, and $\mathrm{CO}$ and $\mathrm{CO}_{2}$ concentrations) are all contained within the limits of acceptable safety for tunnel users.

The results of the exposure to toxic gases and heat along the evacuation path, expressed in terms respectively of $\mathrm{FED}_{\text {toxic gases }}$ and $\mathrm{FED}_{\text {heat, }}$, also confirm that the tunnel users can safely evacuate.

The present paper has shown that mechanical ventilation is not necessary in the case of the tunnel investigated. However, engineers must always conduct a risk analysis of tunnels with a length less than $1 \mathrm{~km}$ that demonstrates the efficiency of natural ventilation.

The CFD modeling presented in the present paper has a general validity. Therefore, the results obtained might be extended to other tunnels naturally ventilated with similar geometric and traffic characteristics.

Although the authors are confident that they have performed an appropriate analysisbased on the optimization of mesh in FDS and the use of a suitable convergence criterion in Evac-which contributes towards increasing our knowledge, there are still certain points that should be investigated. Risk analysis should be done also neglecting natural ventilation due to piston effect or in consideration of adverse wind situations (i.e., wind blowing in a direction opposite to the traffic flow). The effects of using a one-way tunnel for bidirectional traffic in specific emergency circumstances should also be investigated.

Therefore, additional studies are needed for making further developments possible in assessing the risk of users in road tunnels that are not mechanically ventilated.

Author Contributions: Conceptualization, C.C., G.G., and I.R.; methodology, C.C., G.G., and I.R.; software, C.C., G.G., and I.R.; validation, C.C., G.G., and I.R.; formal analysis, C.C., G.G., and I.R.; investigation, C.C., G.G., and I.R.; data curation, C.C., G.G., and I.R.; writing-original draft preparation, C.C., G.G., and I.R.; writing-review and editing, C.C., G.G., and I.R.; visualization, C.C., G.G., and I.R.; supervision, C.C. All authors have read and agreed to the published version of the manuscript.

Funding: This research received no external funding.

Institutional Review Board Statement: Not applicable.

Informed Consent Statement: Informed consent was obtained from all subjects involved in the study.

Data Availability Statement: The data presented in this study are available on request from the corresponding author. The data are not publicly available due to privacy restrictions.

Conflicts of Interest: The authors declare no conflict of interest.

\section{Nomenclature}

\section{Symbol}

AADT

FED

g

HGV

$\mathrm{L}$

Q

q

$\mathrm{T}$

VHP
Value

10,000

9.81

Greek symbols

$\Delta \mathrm{t}$

$\begin{aligned} & \text { Unit } \\ & \text { vehicles/day per lane }\end{aligned}$
$\mathrm{m} / \mathrm{s}^{2}$
$\mathrm{~m}$
$\mathrm{~W}$
$\mathrm{~kW} / \mathrm{m}^{2}$
${ }^{\circ} \mathrm{C}$
$\mathrm{min}$
vehicles/hour

$\min$

\author{
Description \\ Annual Average Daily Traffic \\ Fractional Effective Dose \\ Gravity acceleration \\ Heavy Good Vehicle \\ Tunnel length \\ Heat Release Rate (HRR) \\ Radiant heat flux \\ Temperature \\ Time \\ Peak hour of traffic volume
}

Exposure time interval $\left(t_{2}-t_{1}\right)$ 


\begin{tabular}{|c|c|c|c|}
\hline $\begin{array}{l}\delta_{\mathrm{x}} \\
\rho_{\infty} \\
\text { Sup and subscripts }\end{array}$ & 1.2 & $\begin{array}{l}\mathrm{m} \\
\mathrm{kg} / \mathrm{m}^{3}\end{array}$ & $\begin{array}{l}\text { Nominal size grid } \\
\text { Air density }\end{array}$ \\
\hline$c_{\mathrm{p}}$ & 1 & $\mathrm{~J} / \mathrm{kg} / \mathrm{K}$ & Air specific heat \\
\hline $\mathrm{CN}$ & & & Cyanide \\
\hline $\mathrm{CO}$ & & & Carbon monoxide \\
\hline $\mathrm{CO}_{2}$ & & & Carbon dioxide \\
\hline $\mathrm{D}^{*}$ & & $\mathrm{~m}$ & Characteristic length scale \\
\hline $\mathrm{FED}_{\mathrm{CN}}$ & & & Fraction of an incapacitating dose of $\mathrm{CN}$ \\
\hline $\mathrm{FED}_{\mathrm{CO}}$ & & & Fraction of an incapacitating dose of $\mathrm{CO}$ \\
\hline FLD $_{\text {irr }}$ & & & Fraction lethal dose of irritants \\
\hline $\mathrm{FED}_{\mathrm{NO}_{\mathrm{x}}}$ & & & Fraction of an incapacitating dose of $\mathrm{NO}_{\mathrm{x}}$ \\
\hline $\mathrm{FED}_{\mathrm{O}_{2}}$ & & & Fraction of an incapacitating dose of low $\mathrm{O}_{2}$ \\
\hline $\mathrm{HV}_{\mathrm{CO}_{2}}$ & & & Hyperventilation factor induced by $\mathrm{CO}_{2}$ \\
\hline $\mathrm{NO}$ & & & Nitrogen monoxide \\
\hline $\mathrm{NO}_{2}$ & & & Nitrogen dioxide \\
\hline $\mathrm{NO}_{\mathrm{x}}$ & & & Collective term used to refer to $\mathrm{NO}$ and $\mathrm{NO}_{2}$ \\
\hline $\mathrm{O}_{2}$ & & & Oxygen \\
\hline$t_{1}$ & & $\min$ & Evacuation start time \\
\hline$t_{2}$ & & $\min$ & Evacuation end time \\
\hline $\mathrm{T}_{\infty}$ & 293.15 & $\mathrm{~K}$ & Ambient temperature \\
\hline$t_{\text {Iconv }}$ & $5 \cdot 10^{7} \cdot T^{-3.4}$ & $\min$ & Time to incapacitation due to $T$ \\
\hline$t_{\text {Irad }}$ & $16.67 / q^{1.33}$ & $\min$ & Time to incapacitation due to $q$ \\
\hline$t_{\max }$ & & $\min$ & Time to reach the maximum HRR \\
\hline
\end{tabular}

\section{References}

1. Amundsen, F.H.; Engebretsen, A. Studies on Norwegian Road Tunnels II. An Analysis on Traffic Accidents in Road Tunnels 2001-2006; Raport no: TS4-2009; Statens Vegvesen, Vegdirektoratet, Roads and Traffic Department, Traffic Safety Section: Oslo, Norway, 2009.

2. Lu, J.J.; Xing, Y.; Wang, C.; Cai, X. Risk factors affecting the severity of traffic accidents at Shanghai river-crossing tunnel. Traffic Inj. Prev. 2016, 17, 176-180. [CrossRef] [PubMed]

3. Caliendo, C.; De Guglielmo, M.L. Accident rates in road tunnels and social costs evaluation. Procedia Soc. Behav. Sci. 2012, 53, 166-177. [CrossRef]

4. $\quad$ Beard, A.; Carvel, R. The Handbook of Tunnel Fire Safety; Thomas Telford Ltd.: London, UK, 2005.

5. PIARC. Fire and Smoke Control in Road Tunnels; Technical Committee on Road Tunnels, The World Road Association: Paris, France, 1999.

6. Kumar, S. Recent achievements in modelling the transport of smoke and toxic gases in tunnel fires. In Proceedings of the 1st International Symposium Safe \& Reliable Tunnels, Prague, Czech Republic, 4-6 February 2004.

7. Kashef, A.; Benichou, N. Investigation of the Performance of Emergency Ventilation Strategies in the Event of Fires in a Road Tunnel-A Case Study. J. Fire Prot. Eng. 2008, 18, 165-198. [CrossRef]

8. NFPA 502. Standard for Road Tunnels, Bridges, and Other Limited Access Highways; NFPA: Quincy, MA, USA, 2017.

9. European Parliament and Council. Directive 2004/54/EC. In Official Journal of the European Union. L.167; European Parliament and Council: Bruxelles, Belgium, April 2004.

10. Italian Ministry of Infrastructures and Transports. Adoption of the Directive 2004/54/EC on the Safety of Tunnels Belonging to the Trans-European Road Network; G.U., No. 235; Italian Ministry of Infrastructures and Transports: Rome, Italy, October 2006.

11. Mc-Quade-Jones, K.; Bilson, M. Natural ventilation of a short tunnel. In Proceedings of the Application of FDS+EVAC, Fire and Evacuation Modeling Technical Conference (FEMTC) 2018, Gaithersburg, MD, USA, 1-3 October 2018.

12. Chow, W.K.; Gao, Y.; Zhao, J.H.; Dang, J.F.; Chow, N.C.L. A study on titled tunnel fire under natural ventilation. Fire Saf. J. 2016, 81, 44-57. [CrossRef]

13. Yu, L.; Wei, Z. Experimental study of the influence of natural ventilation by shaft on the maximum ceiling temperature of buoyancy plume in tunnel fires. Tunn. Undergr. Space Technol. 2020, in press. [CrossRef]

14. Zhang, X.; Lin, Y.; Shi, C.; Zhang, J. Numerical simulation on the maximum temperature and smoke back-layering length in a titled tunnel under natural ventilation. Tunn. Undergr. Space Technol. 2021, 107, 103661. [CrossRef]

15. McGrattan, K.; Hostikka, S.; Floyd, J.; McDermott, R.; Vanella, M. Fire Dynamics Simulator: Technical Reference Guide, 6th ed.; National Institute of Standards and Technology, Fire Research Division, Engineering Laboratory: Gaithersburg, MD, USA, 2019.

16. McGrattan, K.; Hostikka, S.; Floyd, J.; McDermott, R.; Vanella, M. Fire Dynamics Simulator: User's Guide, 6th ed.; National Institute of Standards and Technology, Fire Research Division, Engineering Laboratory: Gaithersburg, MD, USA, 2019.

17. Korhonen, T. Fire Dynamic Simulator with Evacuation: FDS+Evac Technical Reference and User's Guide; VTT Technical Research Centre of Finland: Espoo, Finland, 2018. 
18. Caliendo, C.; Ciambelli, P.; De Guglielmo, M.L.; Meo, M.G.; Russo, P. Numerical simulation of different HGV fire scenarios in curved bi-directional road tunnels and safety evaluation. Tunn. Undergr. Space Technol. 2012, 31, 33-50. [CrossRef]

19. Caliendo, C.; Ciambelli, P.; De Guglielmo, M.L.; Meo, M.G.; Russo, P. Simulation of fire scenarios due to different vehicle types with and without traffic in a bi-directional road tunnel. Tunn. Undergr. Space Technol. 2013, 37, 22-36. [CrossRef]

20. Xiaobo, Q.; Qiang, M.; Zhiyuan, L. Estimation of number of fatalities caused by toxic gases due to fire in road tunnels. Accid. Anal. Prev. 2013, 50, 616-621.

21. Chen, L.F.; Hu, L.H.; Tang, W.; Yi, L. Studies on buoyancy driven two-directional smoke flow layering length with combination of point extraction and longitudinal ventilation in tunnel fires. Fire Saf. J. 2013, 59, 94-101. [CrossRef]

22. Valasek, L.; Glasa, J. Simulation of the course of evacuation in tunnel fire conditions by FDS + Evac. In Proceedings of the 2013 International Conference on Applied Mathematics and Computational Methods in Engineering, Sun Valley, ID, USA, 5-9 May 2013; pp. 288-295.

23. Glasa, J.; Valasek, L.; Halada, P.; Weisenpacher, P. Modelling of impact of fire on safe people evacuation in tunnel. J. Phys. Conf. Ser. 2014, 490, 012067. [CrossRef]

24. Chow, W.K.; Gao, Y.; Zhao, J.H.; Dang, J.F.; Chow, C.L.; Miao, L. Smoke movement in tilted tunnel fires with longitudinal ventilation. Fire Saf. J. 2015, 75, 14-22. [CrossRef]

25. Kadlic, M.; Mózer, V. Uncertainties associated with tunnel design fire scenarios. Procedia Eng. 2017, 192, 387-392. [CrossRef]

26. Bosco, D.; Lovreglio, R.; Frassoldati, A.; Derudi, M.; Borghetti, F. Queue formation and evacuation modelling in road tunnels during fires. Chem. Eng. Trans. 2018, 67, 805-810.

27. Caliendo, C.; Ciambelli, P.; De Guglielmo, M.L.; Meo, M.G.; Russo, P. Computational analysis of fire and people evacuation for different positions of burning vehicles in a road tunnel with emergency exits. Cogent Eng. 2018, 5, 1530834. [CrossRef]

28. Jun, W.; Weng, M.; Liu, F. A numerical study of the low-temperature zone in tunnel fires with strong longitudinal ventilation. In IOP Conference Series: Materials Science and Engineering; IOP Publishing: Bristol, UK, 2019; Volume 609.

29. Król, A.; Król, M. The factors determining the number of the endangered people in a case of fire in a road tunnel. Fire Saf. J. 2020, 111, 102942. [CrossRef]

30. Ciambelli, P.; Meo, M.G.; Russo, P.; Vaccaro, S. Natural vs. forced ventilation during fires in relatively short road tunnels. In Proceedings of the 29th Meeting of the Italian Section of the Combustion Institute, Pisa, Italy, 14-17 January 2006.

31. Schrefler, B.A.; Brunello, P.; Gawin, D.; Majorana, C.E.; Pesavento, F. Concrete at high temperature with application to tunnel fire. Comput. Mech. 2002, 29, 43-51. [CrossRef]

32. Steinert, C. Smoke and heat production in tunnel fires. In Proceedings of the International Conference on Fires in Tunnels, Boras, Sweden, 10-11 October 1994; pp. 123-137.

33. FIT-European Thematic Network Fire in Tunnels. Design Fire Scenarios. Technical Report Part 1, A. Haack, STUVA. 2005. Available online: https://www.wtcb.be/homepage/download.cfm?lang=en\&dtype=services\&doc=FIT_Annex2_Technical_ report_part_1_Design_fire_scenarios.pdf (accessed on 15 October 2020).

34. Xue, H.; Ho, J.; Cheng, Y. Comparison of different combustion models in enclosure fire simulation. Fire Saf. J. 2001, 36, 37-54. [CrossRef]

35. DiNenno, P.J.; Drysdale, D.; Beyler, C.L.; Douglas Walton, W.; Custer, R.L.P.; Hall, J.R.; Watts, J.M. The SFPE Handbook of Fire Protection Engineering, 2nd ed.; National Fire Protection Association: Quincy, MA, USA, 1995.

36. Xie, B.; Zhang, S.; Xu, Z.; He, L.; Xi, B.; Wang, M. Experimental study on vertical evacuation capacity of evacuation slide in road shield tunnel. Tunn. Undergr. Space Technol. 2020, 97, 103250. [CrossRef]

37. UPTUN. Workpackage 2-Fire Development and Mitigation Measures. 2008. Available online: https://iwma.net/fileadmin/ user_upload/general/uptun_guidance.pdf (accessed on 15 October 2020).

38. CFPA-E. Fire Safety Engineering Concerning Evacuation from Buildings. European Guideline CFPA-E, No.19. 2009. Available online: http://www.cfpa-e.eu/wp-content/uploads/files/guidelines/CFPA_E_Guideline_No_19_2009.pdf (accessed on 15 October 2020). 